hoping, at Easter, that an outspoken declaration would jolly the profession along for a few months or so. The growls of discontent he left behind should have convinced him that this is a turning point in the history of British education, and that he should take the lead in finding out what should happen to it next.

\section{TRIBOLOGY FOR ALL}

$I^{\mathrm{F}}$ you give a dog a good name, you have more hope of sanctifying him. This principle seems to have guided the British working party on lubrication which has now reported to the Department of Education and Science (Lubrication, H.M.S.O., 6s. 6d.). It is no excuse that the editors of the Oxford English Dictionary are said to have helped in coining the word 'tribology" for "the science and technology of interacting surfaces in relative motion and the practices related thereto". There is nothing wrong with the word, but only with the amalgam of pomposity and special pleading which had led the working party to undermine a good case by wild exaggeration.

The working party starts off on the wrong foot with the calculation that British industry could save some $£ 515$ millions a year by making full use of what is called tribotechnology. Obviously there are savings to be madein reduced energy consumption, reduced lubrication costs, savings on spare parts and because properly designed and lubricated machinery should last longer. Better tribology could also reduce losses of industrial output caused by unexpected breakdowns. But is it sensible to suppose that industry could realistically hope to win all these benefits by better practice? Or that it would be wise to try? There may indeed be many circumstances when bad practice is cheapest and therefore best. As with fuel efficiency or the prevention of corrosion, it is necessary always to balance potential benefits against the costs of attaining them. The working party has naïvely forgotten this rule.

The report does not recover from this bad beginning. It says, for example, that only "a small minority" of the 200,000 technicians in the metal and engineering industries have a "working knowledge" of lubrication, but does not go through what would have been the valuable exercise of saying what a working knowledge should consist of. There is a lot in the working party's argument that there should be more lubrication research in Britair, and better liaison with and a more intimate involvement of the universities. Obviously it would also help a great deal if there could be more short courses for practising engineers and technicians. But it is hard to see what is intended by the recommendation that tribology should sometimes be "offered as an optional subject in the last year of engineering first degree courses". The working group has evidently fallen into the old fallacy of British education-the view that if a topic is thought to be important, it should be possible for a few specialists to study it to the exclusion of most other things. By recommending "several' institutes of tribology, and "organized professional institution activities in the subject of "Tribology", the working party repeats the orror of trying to make a portentous speciality out of an activity so important that it should be a part of the equipment of all technologists. It is a relief to sce that this report does not finish with the demand that there should be a Minister of Tribology, with a seat in the Cabinet.

\section{CLASSIFICATION IN PSYCHIATRY}

\section{Personality and Personal IIIness}

By G. A. Foulds, in collaboration with 'T. M. Caine, and with the assistance of Anne Adams and Anna Owen. Pp. xi +344. (London: Tavistock Publications, Ltd., 1965.) 55s, net.

CLASSIFICATION is a painful subject in psychiatry. 4 No one can do without it, and no one likes it. At times it has taken the form of multiple divisions and subdivisions, as in medicine generally; Boissier de Sauvages, using a Linnean model, recognized 2,700 types of disease. At other times excessive classification was denounced : Adolf Meyer, the outstanding psychiatrist of the United States, groaned at "veritable debauches of unwarranted systematization" and declared that hankering after premature groupings was "excusable in a naïve statistician but not in a modern clinician". The statisticians, among whom many psychologists may now bo included, do not by any means regard themselves as naive in this matter. They have grappled with the problem, and, as Dr. Foulds clearly shows, have contrived ingenious ways of setting about it. Their work has reached the stage at which there is contention about methods and interpretation. Dr. Foulds is a notable contributor to the subject, who has worked alongside psychiatrists and acquainted himself with their diagnostic procedures, but developed his independent approach.

Initially and throughout he emphasizes the difference between traits of personality and the symptoms and signs of illness. It seems an obvious point, but some psychologists who have worked in this area have overlooked it. He then says, quite rightly, that the system of diagnostic classification used by psychiatrists is logically inadequate, intermingling as it does classes defined by major cause with classes defined by manifest anomalies of behaviour, and with classes defined by course of development or even by adequacy of social compliance. The hotch-potch has its merits and its empirical justification, but Dr. Foulds, like many before him, would greatly prefer a more cohesive system. The product of his efforts in this direction makes up the main body of Personality and Personal Illness.

He starts from the premise that every mental illness is a disorder "of the person, not merely of the organism", and that it is characterized by a failure, of varying extent, to maintain mutual personal relationships. He comes to the conclusion that there is a continuum of increasing failure as one passes from normality to personality disorders, neuroses, psychoses, and at last to non-integrated psychoses (by which he means psychoses in which the patient has lost awareness of himsolf as agent). He has investigated the problem mainly by the use of two questionnaires. One, devised by his collaborator, T. M. Caine, measures a component in personality which he calls 'hysteroid-obsessoid'; the other is an inventory which deliberately does not cover traits but only the symptoms and signs that betoken illness. Using the scores on the questionnaire and this symptom-sign inventory as valid quantitative criteria for mental disorder and personality respectively, he shows that in his subjects the illness measure, that is, the inventory score, changed during treatmont, and that personality measures did not change except in some patients who had lengthy 'community therapy' which altered some of their attitudes.

The work is technically well documented and arguedthough the reader becomes a little tired of the scholastic flavour of some often repeated phrases. It throws some systematic light into a troubled area, and it examines faithfully the faults inherent in psychological methods of enquiry which do not distinguish between personality which is lasting and mental illness which may be transitory, nor between symptoms and the pathological or psychopathological process manifested through them. Some of Dr. Foulds's statements provoke dissont. He 